\title{
ENRICHMENT FACTORS FOR CADMIUM AND LEAD IN SEDIMENT OF GEMBONG ESTUARY, BEKASI, INDONESIA
}

\author{
Stella Feska ${ }^{1}{ }^{凶}$, Muslim $^{2}$, Haeruddin ${ }^{1}$
}

${ }^{1}$ Graduate School of Coastal Resources Management, Faculty of Fisheries and Marine Science, Diponegoro University, 50275 Semarang, Central Java, Indonesia

2 Department of Oceanography, Faculty of Fisheries and Marine Science, Diponegoro University, 50275 Semarang, Central Java, Indonesia

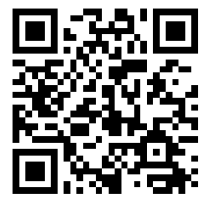

DOI: https://doi.org/10.29121/IJOEST.v5.i2.2021.157

Article Type: Research Article

Article Citation: Stella Feska, Muslim, and Haeruddin. (2021). ENRICHMENT FACTORS FOR CADMIUM AND LEAD IN SEDIMENT OF GEMBONG ESTUARY, BEKASI, INDONESIA. International Journal of Engineering Science Technologies, 5(2), 38-44.

https://doi.org/10.29121/IJOEST.v 5.i2.2021.157

Received Date: 25 January 2021

Accepted Date: 12 March 2021

Keywords:

Heavy Metal

Cadmium

Lead

Enrichment Factor

Quality Standards

\section{ABSTRACT}

The enrichment factors of $\mathrm{Cd}$ and $\mathrm{Pb}$ were determined in Gembong estuary as the biggest estuary in and polluted in Indonesia. Heavy metals over a period of time sooner or later will cause damage to aquatic ecosystems. $\mathrm{Cd}$ (cadmium) and $\mathrm{Pb}$ (lead) are non-essential metals. Various human activities both industrial and domestic around Gembong estuary waters have the potential to degrade the quality of the water. The purpose of this study is to analyze the content and enrichment factors of $\mathrm{Cd}$ and $\mathrm{Pb}$ in sediment. The study was conducted in October 2019 at the high tide and low tide. The method used was quantitative. Heavy metal analysis using the Atomic Absorption Spectrophotometer (AAS AA-7000). The result showed that the concentrations of heavy metals contained in the sediment at the high tide were $\mathrm{Cd}(0.345-1.261 \mu \mathrm{g} / \mathrm{g})$ and $\mathrm{Pb}(13.200-47.600 \mu \mathrm{g} / \mathrm{g})$ and at

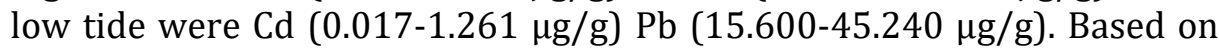
IADC/CEDA quality standard criteria (1997). The standard quality criteria for $\mathrm{Cd}(0.8 \mu \mathrm{g} / \mathrm{g})$ means that the concentration of $\mathrm{Cd}$ at high tide and low tide have exceeded the quality standard. Meanwhile, for $\mathrm{Pb}(85 \mu \mathrm{g} / \mathrm{g})$, the concentration of $\mathrm{Pb}$ at high tide and low tide was still below the target level of quality standards. The enrichment factor values for $\mathrm{Cd}$ at the high tide and low tide fall into the moderate-very high enrichment category. The enrichment factor values for $\mathrm{Pb}$ at the high and low tide was in the moderate-high enrichment category.

\section{INTRODUCTION}

The presence of heavy metals cadmium and lead in aquatic environments constitutes a major risk and concern with fear, thus it needs for continuous monitoring (Usese et al., 2017). Gembong estuary is mouth of Citarum river that upper course from Wayang mountain. This estuarine is very dinamic because it is a confluence area between the Citarum river and the sea from the coast of Jakarta Bay (Aliyanta et al., 2018). Citarum river flows passing some regencies and the ending in Gembong estuary of Bekasi regency. This estuary considered as polluted area, because the water quality in this estuary is grossly polutted. Along the river there are many industrial buildings that use the river as a shipping channel and waste disposal without sufficient prior handling or pay less attention to environmental quality (Birry and Muetia, 2012). Based on a study conducted by the Regional Environmental Management Agency of West Java Province in 2007, there are 359 companies divided into 11 different industrial

(C) 2021 The Author(s). This is an open access article distributed under the terms of the Creative Commons Attribution License, which permits unrestricted use, distribution, and reproduction in any medium, provided the original author and source are credited. 
sectors located in four administrative areas along the upstream flow of the Citarum river. Meanwhile, the company directory issued by the Ministry of Industry's data and Information center (2012) showed an increase in industrial population in several sectors, such as agriculture, textile, leather tanning, food and electroplating industry. Among these industrial sectors, the textile industry is one of the most dominant sectors that produce a lot of heavy metals cadmium and lead wastes.

Heavy metals that enter to the waters continuously and continue to increase can cause toxic and persistence to most aquatic and human biota and a threat to aquatic ecosystems (EPA, 2004). Over time, heavy metals that enter the waters will settle and are contained in the sediment through the process of gravity (Permata et al., 2018) and can affect water quality (Dou et al., 2013). Estuarine and continental shelf are the important sink for settleable suspended solidsand biota in sediment associated with trace metal contaminants(Yeats \& Bewers, 1982) and (Lo \& Fung, 1992).

Research on the concentration of $\mathrm{Cd}, \mathrm{Cr}$ and $\mathrm{Pb}$ in the along Citarum river has been carried out and the results are that in the downstream areas are detected higher than in the upstream area (Habibi et al., 2014). All the waste arrived at the estuarine, it will settle to the bottom of the sediment, and eventually it will always increase with time.

Although many studies have been done on related to heavy metals in Gembong estuary (Arief et al., 2012); (Ambinari et al., 2016) and (Tidjani et al., 2016), but no information is available on enrichment factors of some trace metals. With regard to the increased accumulation pollutants in sediments especially for $\mathrm{Cd}$ and $\mathrm{Pb}$ in time, it is necessary to do research on the enrichment factor. Enrichment Factor (EF) has been used as diagnostic tools for assessing the pollution status of some trace metals (Likuku et al., 2013) and (Nowrouzi \& Pourkhabbaz, 2014).

In the present study was carried out in order to : (1) Determine the level concentration of trace metals Cd and $\mathrm{Pb}$ in sediment and the safety level in terms of quality standards. (2) The enrichment factors of $\mathrm{Cd}$ and $\mathrm{Pb}$ that is determined for measuring containing range of $\mathrm{Cd}$ and $\mathrm{Pb}$ in sediment.

This research could be useful to determine the condition of the waters of the Gembong estuary, which can then be used in determining the management of its handling.

\section{MATERIAL AND METHOD}

Field sampling and sample treatment: Sediments sampling was carried out at Gembong estuary waters on October 31, 2019. The fields stations as shown in Fig.1. The coordinates and depths of the sampling stations are presented in Table 1 . Approximately $2 \mathrm{~kg}$ wet sediment were obtained using Van-Veen grab sampler during the water in high tide and low tide. Sediment samples were then placed in plastic bag and transported to laboratory.

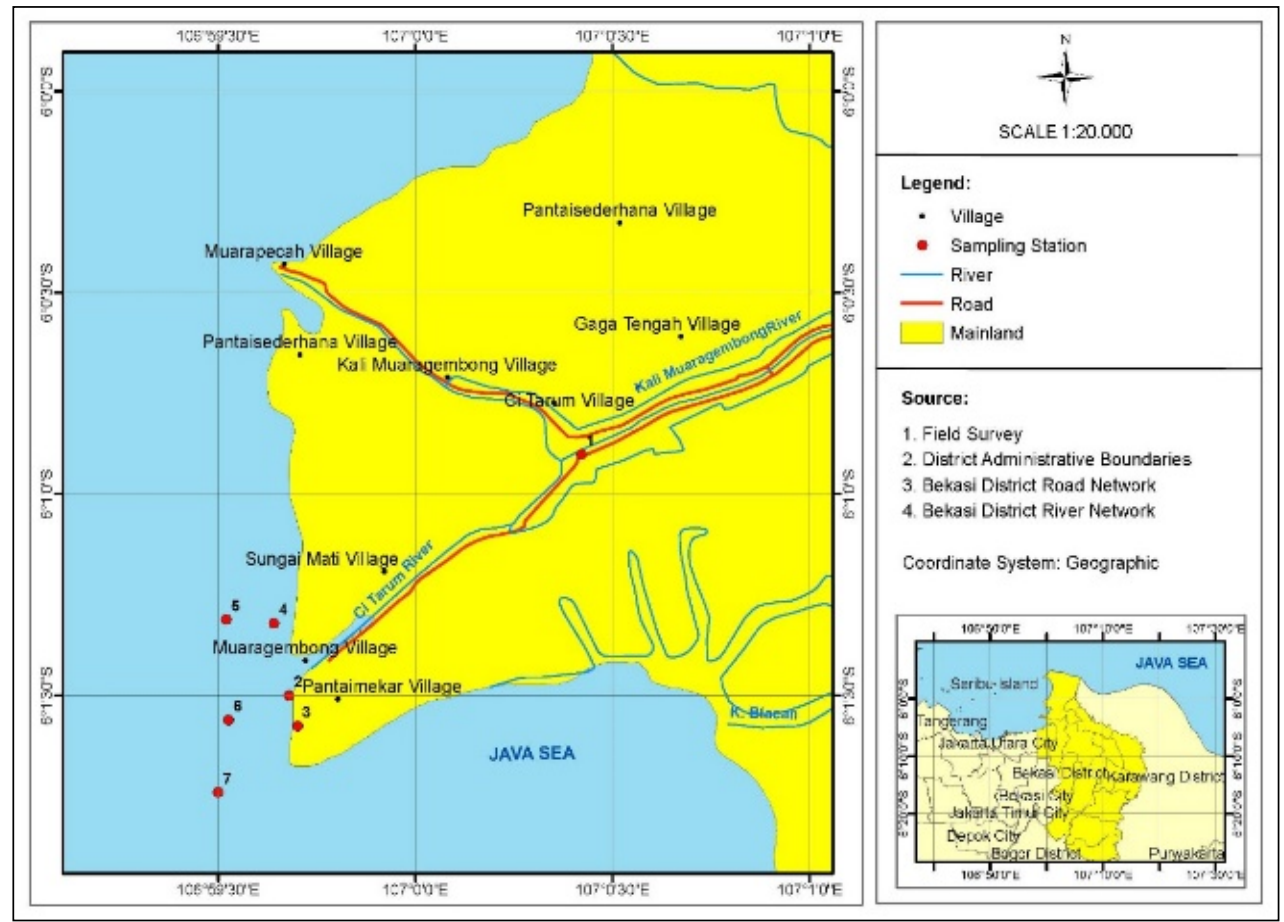

Figure 1: Sampling station sites, Bekasi, Indonesia. 
Table 1: Station sites information

\begin{tabular}{|c|c|c|c|c|}
\hline \multirow{2}{*}{ Station } & \multicolumn{2}{|c|}{ Coordinate } & Depth at high tide (m) & Depth at low tide (m) \\
\cline { 2 - 3 } & Longitude & Latitude & & \\
\hline 1 & $107^{\circ} 00^{\prime} 25.13^{\prime \prime}$ & $06^{\circ} 00^{\prime} 54.04^{\prime \prime}$ & 1.28 & 0.60 \\
\hline 2 & $106^{\circ} 59^{\prime} 40.71^{\prime \prime}$ & $06^{\circ} 01^{\prime} 28.99^{\prime \prime}$ & 1.18 & 0.22 \\
\hline 3 & $106^{\circ} 59^{\prime} 41.01^{\prime \prime}$ & $06^{\circ} 01^{\prime} 34.51^{\prime \prime}$ & 0.69 & 0.20 \\
\hline 4 & $106^{\circ} 59^{\prime} 38.40^{\prime \prime}$ & $06^{\circ} 01^{\prime} 18.94^{\prime \prime}$ & 1.00 & 0.50 \\
\hline 5 & $106^{\circ} 59^{\prime} 32.60^{\prime \prime}$ & $06^{\circ} 01^{\prime} 18.62^{\prime \prime}$ & 1.24 & 0.38 \\
\hline 6 & $106^{\circ} 59^{\prime} 31.51^{\prime \prime}$ & $06^{\circ} 01^{\prime} 32.81^{\prime \prime}$ & 1.12 & 0.44 \\
\hline 7 & $106^{\circ} 59^{\prime} 29.93^{\prime \prime}$ & $06^{\circ} 01^{\prime} 42.66^{\prime \prime}$ & 1.34 & 0.54 \\
\hline
\end{tabular}

\subsection{SEDIMENTS SAMPLES ANALYSIS}

Laboratory treatment and measurements heavy metals analysis: Sediments were air-dried for two to five days at room temperature. After drying, the samples were disaggregated and any visible remains of organisms and debris removed. Sediments were dried in an oven at $105{ }^{\circ} \mathrm{C}$ until dryness. Before analysis the sediments were then ground using a pestle and mortar and sieved trough a 63-70 microns nylon mesh sieved to normalize particle sizes for total $\mathrm{Cd}$ and $\mathrm{Pb}$ analysis (I. Muslim \& Jones, 2003). The processed sediment samples were thereafter transported under strict quarantine procedure for further processing to the chemical laboratory located at the Jakarta National University. From the dried powdered sediment sample, approximately $5 \mathrm{~g}$ was weighed into an acid washed $100 \mathrm{~mL}$ Pyrex flask. $50 \mathrm{~mL}$ of aqua regia ( $\mathrm{HCl}: \mathrm{HNO} 3$ at a ratio of 3:1). This solution was shaken until homogenous, and left to stand for about 15 minutes in a fume cupboard at room temperature for an initial digestion phase. This solution was then refluxed for about 2 hours and $2 \mathrm{~mL}$ of $\mathrm{HClO} 4$ added. This solution was digested at $110^{\circ} \mathrm{C}( \pm 2$ hours) on the hot plate until the aqua regia had evaporated. Then, it was digested at $180^{\circ} \mathrm{C}$ to dryness. After digestion, sample solutions were cooled to room temperature and made up to $50 \mathrm{~mL}$ with double distilled water and filtered through a Whatman No 1 filter paper. The solution was subsequently measured heavy metals concentration using Atomic Absorption Spectrophotometer (AAS) AA-7000 on wave length $228.94 \mathrm{~nm}, 283.10 \mathrm{~nm}$ and $248.3 \mathrm{~nm}$ for $\mathrm{Cd}, \mathrm{Pb}$ and Fe respectively. Precision and accuracy of trace metals analyses were checked against the standard BCSS-1, which was collected from the Baie des Chaleur by MacLaren Panesearch Ltd, Dartmouth, N.S

Methods for estimating Enrichment Factor (EF): Enrichment Factor (EF) is one of the methods for calculating method for quantifying the degree of metal enrichment in sediments (Abraham \& Parker, 2008) and as a convenient measure of geochemical trend (Hasan et al., 2013) that is used to evaluate coastal contamination and can be used for making comparation between areas (Sinex \& Helz, 1981). This method is suitable for some locations that get below contamination effect for long time period as effect of human activity such as industrial and agriculture activities. To measure the level EF we need comparation between polluted area in the present day trace metal level with their concentrations in standard earth materials such as with IADC/CEDA (1997) or with the recommended values of unpolluted sediments (Hasan et al., 2013) or with metal in Earth's crust(Abraham \& Parker, 2008). According to Aprile and Bouvy (2008) the EF for metal concentration in sediment at all the stations were calculated by the formulation as below:

$$
E F=\frac{X / F e(\text { Sediment })}{X / F e(\text { Earth'scrust })}
$$

Where $\mathrm{X}$ is the metal in sediment that be studied $(\mathrm{Cd}, \mathrm{Pb})$ and $\mathrm{X} / \mathrm{Fe}$ is the ratio of concentration of the trace metal that be studied and iron. According to Kamau (2002) that iron was chosen as the element of normalization, it due to the dominant input to sediment naturally (98\%). The crustal abundance data of Krauskopf and Bird (1967)were used for all EF values.

Sutherland, (2000) had classified of EF into 5 levels

$\mathrm{EF}<2 \quad=$ Low EF

$2 \leq \mathrm{EF}<5 \quad=$ Moderate

International Journal of Engineering Science Technologies 


$$
\begin{array}{ll}
5 \leq \mathrm{EF}<20 & =\text { Significant } \\
20 \leq \mathrm{EF}<40 & =\text { Very high } \\
\mathrm{EF} \geq 40 & =\text { Extremely high }
\end{array}
$$

\section{RESULTS AND DISSCUSSIONS}

The results of $\mathrm{Cd}$ concentration in sediment when water was in high tide and low tide were shown in Figure 2. In the high tide range $0.345 \mu \mathrm{g} / \mathrm{g}$ to $1.261 \mu \mathrm{g} / \mathrm{g}$ with average $0.737 \mu \mathrm{g} / \mathrm{g}$. The lowest concentration occurred in station 3 and the highest concentration occurred in station 2. Meanwhile, at low tide concentration rage $0.017 \mu \mathrm{g} / \mathrm{g}$ to $1.261 \mu \mathrm{g} / \mathrm{g}$ with average $0.466 \mu \mathrm{g} / \mathrm{g}$ and the lowest concentration occurred in station 7 and the highest concentration occurred in station 2.

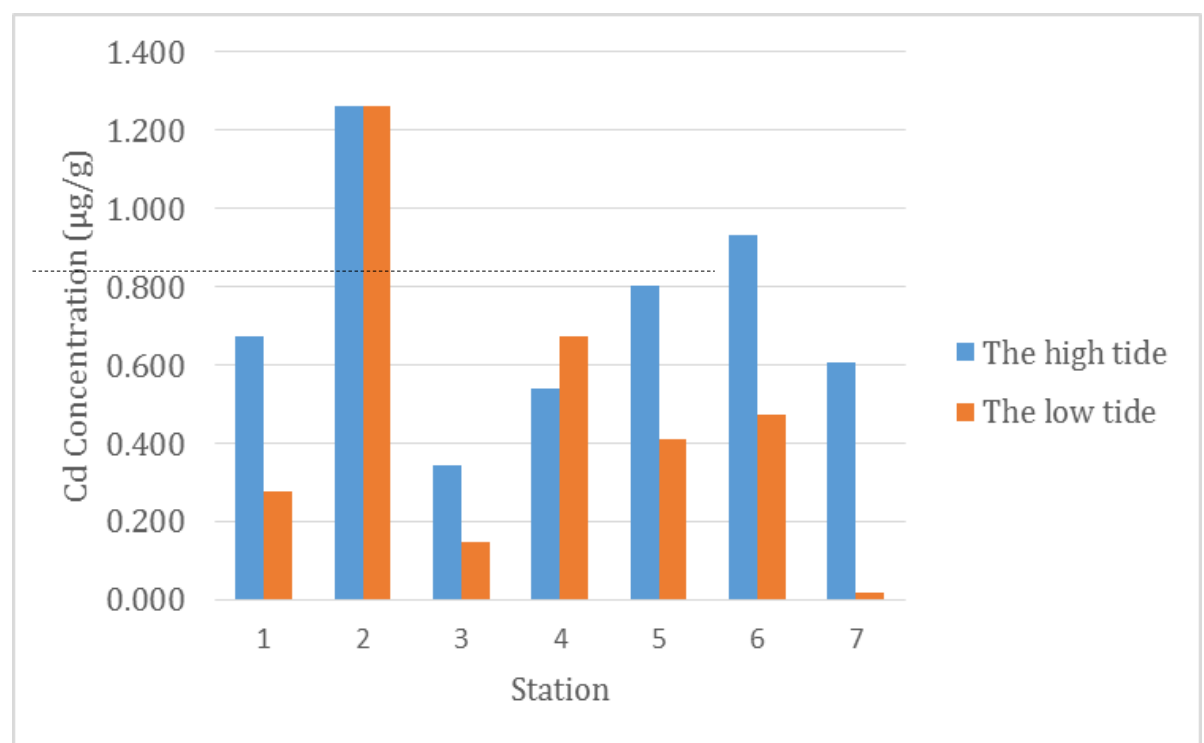

Figure 2: Cd concentration in sediment when water was in high tide and low tide, Gembong estuary, Bekasi, Indonesia.

Note:

$$
\text { = Quality Standard limits IADC/CEDA }(0.8 \mu \mathrm{g} / \mathrm{g})
$$

The highest Cd concentration occurred in station 2 both in the high tide and low tide, it may due to the location of station 2 in the mouth of the river, where there is confluence between water from the sea and river occurred in this station, then deposition of Cd occurs together with suspended solid. It means that this station become a trap of $\mathrm{Cd}$ in sediment. Whereas in other stations the concentration fluctuates greatly, due to the influence of location condition which are influenced by dilution(M. Muslim \& Wahyu Retno, 2017), resuspension (Muslim \& Jones, 2003), Muslim et al., 2015), and deposition is caused by chemical binding (M. Muslim et al., 2015) \& (Alviandini et al., 2019).

According to Rumahlatu (2011) state that industrial activities that produce a lot of Cd waste are paint dyes (such as painting coastal building and ship) and PVC plastic. While human activities that contribute to Cd are the use of pesticide. According to quality standard level IADC/CEDA (1997) that the concentration of Cd in station 2 and 6 have exceeded the allowable limit ( $>0.8 \mu \mathrm{g} / \mathrm{g}$ ). Meanwhile, according to the United States Environmental Protection Agency (EPA, 2004), all stations still meet the quality standards $(<0.6 \mu \mathrm{g} / \mathrm{g})$.

$\mathrm{Pb}$ concentration at high tide and low tide are shown in Figure 3. The fluctuation of the $\mathrm{Pb}$ concentration looks very different from the fluctuation of $\mathrm{Cd}$. This is due to the difference in sources of $\mathrm{Pb}$ and $\mathrm{Cd}$, where $\mathrm{Pb}$ is dominated by fuel smoke in the atmosphere, while $\mathrm{Cd}$ comes from industrial waste which is directly discharge into the water.

Concentration of $\mathrm{Pb}$ range $13.20 \mu \mathrm{g} / \mathrm{g}$ to $47.60 \mu \mathrm{g} / \mathrm{g}$ with average $32.526 \mu \mathrm{g} / \mathrm{g}$ in the high tide. The highest $\mathrm{Pb}$ concentration occurred at station 1 , where in this place there is a pier and a fish auction place, so that many ships unload and load goods and fish which produce a lot of $\mathrm{Pb}$ waste from the fuel smoke produce. The lowest $\mathrm{Pb}$ concentration occurred at station 5 , this is because station 5 is located far from the river as a source of Pb. Whereas at low tide the $\mathrm{Pb}$ concentration ranges from $15.60 \mu \mathrm{g} / \mathrm{g}$ to $45.24 \mu \mathrm{g} / \mathrm{g}$ with an average $30.509 \mu \mathrm{g} / \mathrm{g}$. The highest Pb 
concentration occurred at station 2 which is located in the mouth of river as a trap for sediments particles with several elements and the lowest concentration occurred at station 7 which is located far from the mouth of the river so that it has undergo dilution.

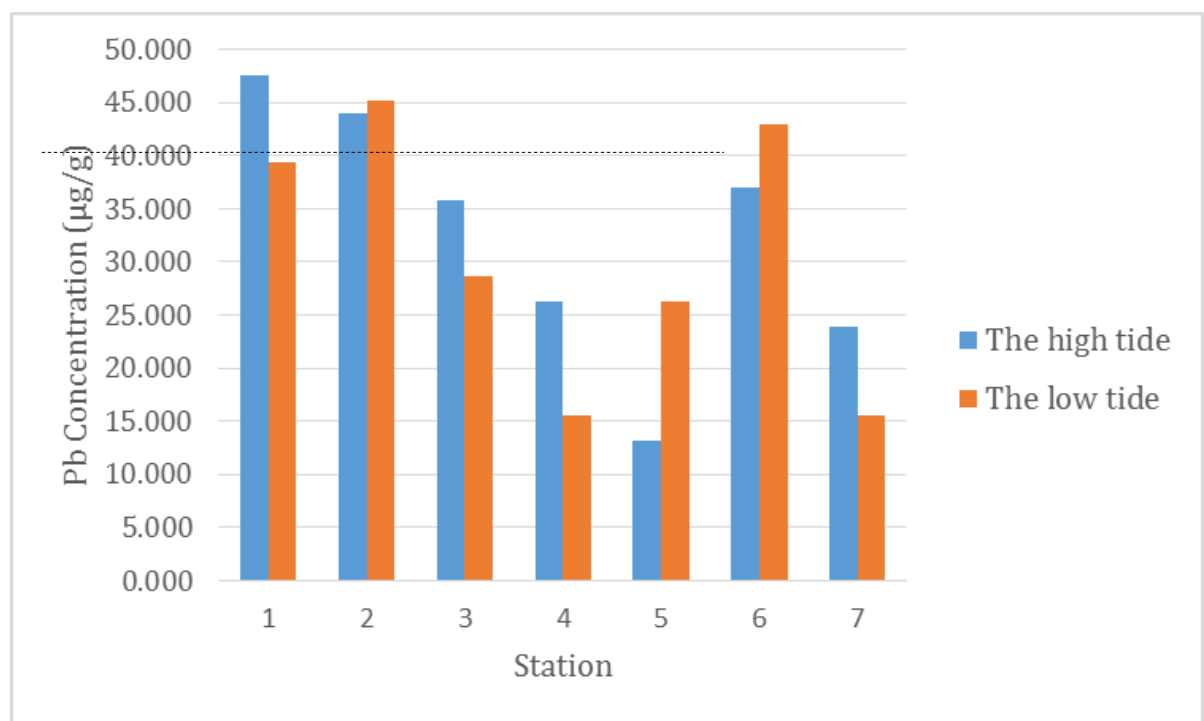

Figure 3: Pb concentration in sediment when water was in high tide and low tide, Gembong estuary, Bekasi, Indonesia.

Note:

$=$ Quality standard limits = moderat polluted United States Environmental Protection Agency $(40 \mu \mathrm{g} / \mathrm{g})$

Base on the quality standard according to IADC/CEDA (1997), the concentration is said be safe if the Pb concentration in the sediment is still below $85 \mu \mathrm{g} / \mathrm{g}$, so that the waters of Gembong are still in the safe category. However, based on EPA (2004) which says it is safe if the concentration of Pb is still below $40 \mu \mathrm{g} / \mathrm{g}$, so stations 1,2 and 6 are no safe.

The high concentration of $\mathrm{Pb}$ at stations 1, 2 and 6 is because these stations are in direction of river water flow. and exceed the quality standard both at high tide and low tide occur at stations 1,2 and 6, where these stations are in one direction with water river flow from upstream to downstream. Furthermore, at other stations the concentration decreases at the farther from the water river flow, this is due to the dilution process.

Enrichment Factors (EF): To evaluate the level of $\mathrm{Cd}$ and $\mathrm{Pb}$ contamination, it is necessary to measure Enrichment Factors (EF). The result of EF measurement at high tide can be seen in Figure 4. The EF value for Cd in the high tide ranged 11.444 to 41.804 , it is in the category significant to extremely high, and the average was 24.349 which is in the category very high. While the EF value of $\mathrm{Pb}$ at high tides ranged 6.718 to 24.361 which in the EF category significant to very high, and the average was 16.536 , which is in the category significant.

Table 2: Enrichment Factors for $\mathrm{Cd}$ and $\mathrm{Pb}$ in the high tide

\begin{tabular}{|c|c|c|}
\hline \multirow{2}{*}{ Station } & \multicolumn{2}{|c|}{ Enrichment Factor } \\
\cline { 2 - 3 } & $\mathrm{Cd}$ & $\mathrm{Pb}$ \\
\hline 1 & 22.357 & 24.361 \\
\hline 2 & 41.804 & 22.462 \\
\hline 3 & 11.444 & 18.248 \\
\hline 4 & 17.805 & 13.307 \\
\hline 5 & 26.566 & 6.719 \\
\hline 6 & 30.698 & 18.667 \\
\hline 7 & 19.775 & 11.988 \\
\hline
\end{tabular}

The value of the $\mathrm{EF}$ for $\mathrm{Cd}$ and $\mathrm{Pb}$ at the lowest tide can be seen in Figure 5. The EF value for Cd ranged 0.549 to 41.178, which in the category Low EF to Extremely high, and the average value was 15.1387 which in the category 
Significant. While, the EF value for Pb ranges 7.746 to 22.728 which in the category significant to very high and the average vale was 12.108 which in the category significant.

Table 3: Enrichment Factors for $\mathrm{Cd}$ and $\mathrm{Pb}$ in the low tide

\begin{tabular}{|c|c|c|}
\hline \multirow{2}{*}{ Station } & \multicolumn{2}{|c|}{ Enrichment Factor } \\
\cline { 2 - 3 } & $\mathrm{Cd}$ & $\mathrm{Pb}$ \\
\hline 1 & 9.180 & 19.904 \\
\hline 2 & 41.178 & 22.728 \\
\hline 3 & 4.798 & 14.284 \\
\hline 4 & 21.726 & 7.759 \\
\hline 5 & 13.176 & 12.993 \\
\hline 6 & 15.364 & 21.338 \\
\hline 7 & 0.549 & 7.746 \\
\hline
\end{tabular}

This shows that the presence of $\mathrm{Pb}$ at high and low tide also $\mathrm{Cd}$ at low tide was influenced by natural and anthropogenic activities. Whereas the presence of $\mathrm{Cd}$ at high tide is strongly influenced by anthropogenic activities. Very high level of enrichment factors cause high concentrations of heavy metal and can affect organisms in a marine ecosystem. Heavy metals that suspended in the water eventually accumulate in the bottom sediments. Heavy metals in the bottom sediments can be accumulated by benthic organisms, where benthic organisms form the basis of the food chain and eventually become metal transfer agents from basic sediments to higher levels of tropics (Putra and Apriadi, 2018).

\section{CONCLUSIONS}

Based on this study, it can be concluded from quality standards of IADC/CEDA (1997) that the Cd concentration in waters of Gembong estuary has exceeded the quality standards, while for Pb concentration still on the quality standard. The enrichment factors of $\mathrm{Cd}$ and $\mathrm{Pb}$ at Gembong estuary is included in the minimal to very high enrichment category, which indicates that the source of heavy metals is mostly anthropogenic. The higher enrichment factor of heavy metal in a waters, it will have an impact on the aquatic ecosystem if it is not managed optimally.

\section{SOURCES OF FUNDING}

This research received no specific grant from any funding agency in the public, commercial, or not-for-profit sectors.

\section{CONFLICT OF INTEREST}

The author have declared that no competing interests exist.

\section{ACKNOWLEDGMENT}

The authors would like to thank Dr. Pujiono Wahyu Purnomo and Dr. Bambang Sulardiono for the support in this manuscript. The authors also thank to reviewers for their valuable comments to revise the paper.

\section{REFERENCES}

[1] Abrahim, G.M.S., and R.J. Parker. 2008. Assessment of Heavy Metal Enrichment Factors and The Degree of Contamination in Marine Sediments from Tamaki Estuary, Auckland, New Zealand. Environ Monit Assess, 136: 227-238. 
[2] Aliyanta, B., A. Khairina, A. Kartikasari, and A.A. Lubis. 2018. Estimation of The Rate of Sediment Deposition in Estuary of Gembong Citarum River. A Scientific Journal for The Applications of Isotopes and Radiation, 14 (1): 11-20.

[3] Alviandini, N.B., Muslim., W.R. Prihatiningsih and S.Y. Wulandari. 2019. NORM Activity on Sediment Basement in the Waters of PLTU Tanjung Jati Jepara Water and Its Relation to Sediment Grain Size and TOC. Eksplorium, 40(2):115-126.

[4] Ambinari, M.D., D. Darusman,H.S. Alikodra and N. Santoso. 2016. Reforming the Role of the Parties in Urban Mangrove Forest Managements (Case Study on Mangrove Forest Management in Jakarta Bay). Jurnal Analisis Kebijakan, 13 (1): 29-40.

[5] Aprile, F.M., and Bouvy, M. 2008. Distribution and Enrichment of Heavy Metals in Sediments at The Tapacura River Basin, Northeastern Brazil. Braz. J. Aquat. Sci. Technol, 12(1):1-8.

[6] Arief, H.R., Masyamsir., and Y. Dhahiyat. 2012. Distribution of Heavy Metals Content Pb and Cd in Water Column and Sediment of Upper Citarum River Sediments. Jurnal Perikanan dan Kelautan, 3(3):175-182.

[7] Birry, A.S. and H. Meutia. 2012. Out of Control Toxic Substances, A Portrait of Hazardous and Toxic Chemical Pollution in River Bodies and Some Unmanned Industrial Disposal Points, Citarum Case Study. Greenpeace Indonesia, Jawa Barat. (Indonesian).

[8] Habibi, M., W.W. Lamawuran, and W.A. Rina. 2014. Citarum River Pollution Case Study. [Paper]. Program Pasca Sarjana Fakultas Kesehatan Masyarakat Universitas Airlangga.

[9] IADC/CEDA Staff. 1997. Environmental Aspects of Dredging: 2a. Convention, Codes, and Conditions: Marine Disposal. Netherlands: International Association of Dredging Companies.

[10] Kamau, J.N. 2002. Heavy metal distribution and enrichment at Port-Reitz Creek, Mombasa. Western Indian Ocean Journal of Marine Science 1, 65-70.

[11] Krauskopf, K.B., and Bird D.K. 1967. Intoduction to Geochemistry. New York: McGraw Hill Book Co.

[12] Lo, C.K. and Y.S. Fung. 1992. Heavy Metal Pollution Profiles of Dated Sediment Cores From Hebe Haven, Hong Kong. Water Research, 26 (12): 1605-1619.

[13] Muslim., H. Suseno and M.J. Pratiwi. 2017b. Behavior of 137Cs Activity in the Sayung Waters, Demak, Indonesia. Atom Indonesia, 43 (1): 41 - 46.

[14] Muslim., and G. Jones. 2003. The Seasonal variation of dissolved nutrients, chlorophyll a and suspended sediments at Nelly Bay, Magnetic Island. Estuarine, Coastal and Shelf Science, 57(3):445-455.

[15] Muslim., W.R. Prihatiningsih and R.A. Arjana. 2016. Activity 137Cs and Total Organic Carbon in Sediments around Tikus Island Indian Ocean. J. Kes Rad \& Ling, 1 (1): 6-10.

[16] Permata, M.A.D., A.I.S. Purwiyanto. and G. Diansyah. 2018. Concentration of Heavy Metal Cu (Copper) And Pb (Lead) in The Water and Sediments of Industrial Area, Lampung Bay, Lampung Province. Journal of Tropical Marine Science, 1 (1): 7-14.

[17] Putra, R.D and T. Apriadi. 2018. Study of Heavy Metal Contamination (Pb and Cr) Post Mining Bauxite as Potential of Aquaculture.

[18] Rumahlatu, D. 2011. Concentration Cadmium in Water, Sediment and Deadema setosum (Echinodermata, Echinoidea) in Waters of Ambon Island. Ilmu Kelautan, 16 (2): 78-85.

[19] I.A. Sinex and G.R. Helz. 1981. Regional Geochemistry of Trace Elements in Chesapeake Bay Sediments. Environmental Geology, 3(6): 315-323.

[20] USEPA (National Sediment Quality Survey). 2004. The Incidence and Severity of Sediment Contamination in Surface Waters of United States, National Sediment Quality Survey: 2nd Edition. EPA-823-R-04-2007. U. S. Environmental Protection Agency, Washington D.C.

[21] Usese, A., O.L. Chukwu., M.M. Rahman., R. Naidu., S. Islam and E.O.Oyewo. 2017. Enrichment, contamination and geo-accumulation factors for assessing arsenic contamination in sediment of a Tropical Open Lagoon, Southwest Nigeria. Environmental Technology \& Innovation, 8: 126-131.

[22] Yeats, P.A. and J.M. Bewers. 1982. Discharge of metals from the St. Lawrence River. Canadian Journal of Earth Sciences, 19 (5): 982-992. 